\title{
Do Harmonised Accounting Standards Lead to Harmonised Accounting Practices? An Empirical Study of IAS 39 Measurement Requirements in Some European Union Countries
}

I n 2005 International Financial Reporting Standards (IFRS) were adopted in the consolidated accounts of listed European Union (EU) companies. The objective of this study is to investigate the level of compliance with a complex standard, IAS 39 Financial Instruments: Recognition and Measurement, (IASB 2005) among companies from France, Germany, Italy, Portugal and the United Kingdom (UK). Previous studies have shown that harmonised accounting standards do not necessarily lead to harmonised accounting practices (for example, Cairns 2000; Street et al. 1999; Street and Bryant 2000; Bradshaw and Miller 2008). Some political and economic influences on financial measurement practices remain local and capital markets are not perfectly integrated (Ball 2006). Therefore, some factors (such as legal systems, financial systems, role of the accounting profession, tax alignment and extent of private versus public ownership of companies), which in the past led to differences between accounting systems, may still influence accounting in European countries. Furthermore, the enforcement of financial reporting standards is considered to be an important factor in the promotion of comparable information (CESR 2003). Without an effective worldwide enforcement mechanism, local political and economic factors will continue to exert a substantial influence on local financial reporting practice (Ball 2006).

However, economic globalisation requires increased international comparability in financial reporting, and accounting harmonisation has been seen as an important way for achieving more reliable, credible and comparable financial information at an international level. Therefore, the European Parliament and the Council issued regulation $1606 / 2002$ in 2002, which requires publicly listed European companies to adopt International Accounting Standards Board (IASB) standards in the preparation and presentation of consolidated accounts for the periods beginning on or after 1 January 2005. Companies have incentives to comply with IFRS. Prior studies indicate that companies complying voluntarily with IFRS have a higher accounting quality (Barth et al. 2008) and a lower cost of capital (Leuz and Verrechia 2000).
The objective of this paper is to investigate the level of harmonisation for IAS 39 Financial Instruments: Recognition and Measurement and to identify if different levels of harmonisation are associated with company-specific factors. Based on Rahman et al. (2002), we used the Jaccard (JACC) index to determine the level of harmonisation between IAS 39 and the financial reporting practice of a broad-based sample of European-listed companies in 2005. We applied regression analysis to identify companies' specific characteristics that affect the level of convergence of the reporting practice of financial instruments. The results of this study show a high level of harmonisation between accounting practices of European companies included in our sample and IAS 39.

JEL Classification: M41

\section{Correspondence}

Ana Isabel Morais, Avenida das Forças Armadas, 1649-026 Lisboa, Portugal. Tel: +00351919058942; email: ana.morais@iscte.pt

doi: 10.1111/j.1835-2561.2008.0027.x 
We investigate whether there is variation in the compliance of European companies with the reporting requirements relating to IAS 39 . Of all the standards issued by the IASB, IAS 39 has caused the most controversy because it requires the adoption of fair value measurement for selected financial instruments. In practice, there are potential problems with the determination of fair value. In some cases, if active liquid markets are not available, companies must estimate the fair value. This increases opportunities for manipulation and may introduce some 'noise' due to imperfect estimation of variables or imperfect or inadequate use of valuation models. Moreover, the fair value measurement approach adopted by IAS 39 differs from the accounting treatments used in Europe under previous local accounting standards, and has resulted in criticism of, and opposition to, the standard in various quarters, most notably the European financial and banking sector (European Central Bank 2004).

To investigate the level of compliance with IAS 39, we use a sample of 203 European-listed companies drawn from five countries: France, Germany, Italy, Portugal and the UK. Our findings indicate a high level of compliance of financial instrument-reporting practice with IAS 39. The results also show that the level of compliance with IAS 39 is greater for financial institutions than for other companies. However, we find no persuasive support for other factors (auditor, size, being cross-listed, profitability and number of years of IFRS adoption) being related to the level of compliance with IAS 39.

In this study we aim to provide evidence on the extent of mandatory IAS/IFRS 39 compliance in the first period that companies were required to adopt the standards. This study is to provide evidence on the extent of IAS 39 compliance in jurisdictions where the adoption of IAS/IFRS is mandatory. Most previous IAS compliance studies used samples of companies that adopted IFRS voluntarily (Street et al. 1999; Tower et al. 1999; Street and Bryant 2000). We also investigated compliance with IAS/IFRS 39 in the first period that companies were required to adopt the standards. As IFRS 1 First-time Adoption of International Financial Reporting Standards (IASB 2004) paragraph 1 states, it is important to assure that the first financial statements prepared and presented under IFRS contain high-quality information that is transparent for users is comparable over all periods presented, and that provides a suitable starting point for accounting under IFRS. Our study suggests that companies have achieved high levels of compliance, which is a positive signal in capital markets.

\section{Literature Review}

Our study is related to three main streams of investigation into accounting harmonisation and the level of compliance with IFRS: (1) analysis of the level of compliance with IFRS; (2) study of the level of harmonisation of accounting practices followed by companies from different countries (material harmonisation); and (3) exa-mination of the level of disclosure of information about financial instruments.

Table 1 presents a summary of some of the important prior studies that concern the level of compliance with accounting standards and the company-specific factors that affect the level of accounting practices harmonisation. Those studies show that the level of accounting practices harmonisation (material harmonisation) is related not only to accounting standards harmonisation (formal harmonisation), but also to company-specific factors such as auditors, country of domicile and listing status. However, Table 1 also indicates that most prior studies have been based on the voluntary adoption of IFRS and, in general, they have not investigated IAS 39 adoption. We investigate the compliance with IAS 39, for a sample of European companies that are required to adopt IASB standards.

\section{Hypotheses and Research Design}

\section{Hypotheses}

The IASB standards are developed for the private sector, for markets where public capital is raised and reporting rules are largely unaffected by taxation requirements. Historically, IASB standards have been influenced by common law countries, like the United States (US) and the UK. However, Portuguese, French, Italian and German institutional and legal environments are different to those in the US and the UK, and these differences affect accounting systems in the former countries (Demirgüç-Kunt and Levine 1999; Faccio and Lang 2002; La Porta et al. 1998, 2006).

We expect that the level of compliance with IAS 39 will be higher for companies in common law countries (UK) than for companies in code law countries (France, Germany, Italy and Portugal) for two main reasons. First, IASB standards are closer to common law accounting standards than standards in code law countries. Second, La Porta et al. $(1998,2006)$ showed that the index of private and public enforcement is higher for the UK than for other European countries. Therefore, it is hypothesised that:

\section{H1: The level of compliance with IAS 39 will be higher for companies in common law countries than for companies in code law countries.}

Previous studies suggest that sector is a significant determinant in the choice of accounting methods (McLeay and Jaafar 2007; Meek et al. 1995; and Cooke 


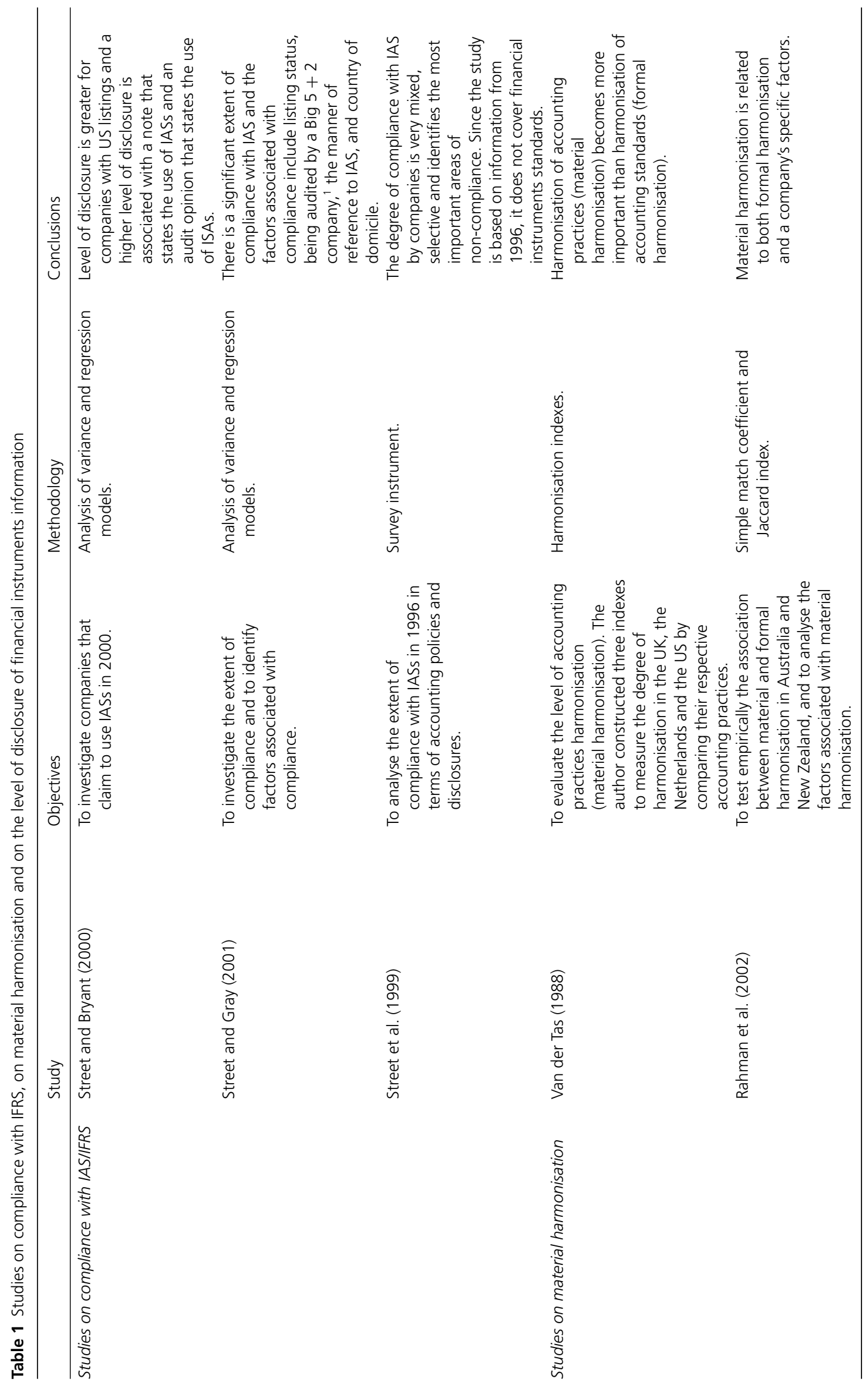







1992) and highlight a relationship between disclosure level and industry sector (Cooke 1992 and Raffournier 1995). Financial institutions are more regulated than companies from other sectors, suggesting a greater incentive to comply with IASB standards than nonfinancial companies. Additionally, it is expected that entities in a given industry may comply more closely with a particular IFRS that is more applicable to their activities (Al-Shammari et al. 2008). Consequently, we expect that financial institutions comply more with IAS 39 , since their activity is closely related with financial instruments. As a result we hypothesise:

\section{H2: The level of compliance with IAS 39 will be higher for financial institutions than in the other sectors.}

Prior research provides some evidence that the level of compliance may be associated with the type of auditor. Auditing is considered to be an important enforcement mechanism. There is evidence that the earnings of US companies with a Big 4 auditor are of higher quality and that the stock market values earnings surprises of Big 4 clients more highly than earnings surprises of companies with non-Big 4 auditors (Teoh and Wong 1993; Krishnan 2003). Additionally, Francis and Wang (2008) find that earnings quality increases for companies with Big 4 auditors, based on an international broadbased sample. As a result, we expect:

H3: The level of compliance with IAS 39 will be higher for companies audited by one of the Big 4 auditors.

Larger companies are more likely to comply with IASB standards for three main reasons. First, larger companies are more visible and tend to act to protect their reputation (Watts and Zimmerman 1978; Holthausen and Leftwhich 1983; Cooke 1989). Second, larger companies tend to have more resources which enable them to comply with new accounting standards (Al-Shammari et al. 2008) Larger companies tend to incur lower costs in accumulating detailed information (Singhvi and Desai 1971; Firth 1979). Finally, smaller companies may be more likely to hide crucial information because of competitive pressures within their industry. Thus it is hypothesised that:

\section{H4: The level of compliance with IAS 39 will be higher in larger companies.}

We expect companies that are listed in more than one market to exhibit a higher level of compliance due to their incentive to make financial reporting more transparent and comparable and to increase the company's credibility. Street and Bryant (2000), Street and Gray (2001), and Glaum and Street (2003) have shown that companies that are cross-listed have higher levels of voluntarily compliance with IAS. Accordingly it is hypothesised that:

H5: The level of compliance with IAS 39 will be higher in companies listed in more than one market.

Prior research regarding the association between profitability and level of compliance reports mixed results. The research of Wallace et al. (1994) and Wallace and Naser (1995) indicate a significant association. However, Al-Shammari et al. (2008) find that profitability is not a statistically significant variable. Nevertheless, we expect more profitable companies to comply more, to signal their 'quality'. This leads to our next hypothesis:

H6: There is an association between profitability and level of compliance with IAS 39.

Finally, we expect that the number of years a company has been complying with IFRS is an important variable in explaining the level of compliance. Therefore, we expect that experience of IFRS will assist companies to achieve compliance. This leads to our final hypothesis:

H7: The level of compliance with IAS 39 will be higher in companies that adopted IFRS before 2005.

\section{Sample}

The sample is based on 220 European-listed companies that are included in the Paris Stock Index (CAC 40), the German Stock Index (DAX 30), the Milan Stock Index (MIB 40), the Portuguese Stock Index (PSI 20) and the London Stock Index (FTSE 100) in 2005, and that are required to adopt IAS 39.

Table 2, panel A shows descriptive statistics for the sample companies in terms of country representation. Of the total companies, we excluded 15 that present their financial reports based on US Generally Accepted Accounting Principles (GAAP) or UK GAAP. For Germany, we excluded eight companies because they did not adopt IFRS in $2005 .{ }^{1}$ A further two companies were excluded because of missing information. Consequently, the number of sample companies was reduced from 220 to 203. In terms of country representation, most of the companies are from the UK (46.8\%).

Table 2, panel B shows representation by industry. The sample comprises 50 companies from the financial sector $(24.6 \%)$ and 153 companies from other sectors (75.4\%). This industry classification shows that most of the companies are from the non-financial sector, except for Italy.

\section{Methodology}

The first objective of this study is to investigate the level of compliance of financial instrument measurement 
Table 2 Companies included in the sample

\begin{tabular}{|c|c|c|c|c|c|c|}
\hline \multicolumn{7}{|c|}{ Panel A: Number of companies included in the sample } \\
\hline Companies & $\begin{array}{l}\text { France } \\
\text { (CAC) }\end{array}$ & $\begin{array}{l}\text { Germany } \\
\text { (DAX) }\end{array}$ & $\begin{array}{l}\text { Italy } \\
\text { (MIB) }\end{array}$ & $\begin{array}{l}\text { Portugal } \\
\text { (PSI) }\end{array}$ & $\begin{array}{c}\text { UK } \\
\text { (FTSE) }\end{array}$ & Total \\
\hline Listed companies & 40 & 30 & 30 & 20 & 100 & 220 \\
\hline US GAAP & - & (8) & $(2)$ & - & $(5)$ & $(15)$ \\
\hline Other & - & (1) & (1) & - & - & $(2)$ \\
\hline Total by country & 40 & 21 & 27 & 20 & 95 & 203 \\
\hline$\%$ by country & $19.7 \%$ & $10.3 \%$ & $13.3 \%$ & $9.9 \%$ & $46.8 \%$ & $100 \%$ \\
\hline \multicolumn{7}{|c|}{ Panel B: Industry analysis } \\
\hline Companies & $\begin{array}{l}\text { France } \\
\text { (CAC) }\end{array}$ & $\begin{array}{l}\text { Germany } \\
\text { (DAX) }\end{array}$ & $\begin{array}{l}\text { Italy } \\
\text { (MIB) }\end{array}$ & $\begin{array}{l}\text { Portugal } \\
\text { (PSI) }\end{array}$ & $\begin{array}{l}\text { UK } \\
\text { (FTSE) }\end{array}$ & $\begin{array}{c}\text { Total } \\
\text { (\% by sector) }\end{array}$ \\
\hline Financial sector & 6 & 4 & 15 & 3 & 22 & $\begin{array}{c}50 \\
(24.6)\end{array}$ \\
\hline Non-financial sector & 34 & 17 & 12 & 17 & 73 & $\begin{array}{c}153 \\
(75.4 \%)\end{array}$ \\
\hline Total by country & 40 & 21 & 27 & 20 & 95 & $\begin{array}{c}203 \\
(100 \%)\end{array}$ \\
\hline
\end{tabular}

practice with IAS 39. To accomplish this goal, we used a self-constructed compliance checklist (see Appendix A), based on the amended IAS 39, as adopted by the European Union $(\mathrm{EU}),{ }^{2}$ and used by the companies included in the sample. The checklist includes 54 items related to financial instruments' measurement methods. In the second column, we assigned the value 1 to the measurement methods required by IAS 39 adopted by the EU and the value 0 to the measurement methods not allowed by IAS 39 adopted by the EU. In the third column, we identified the measurement method adopted by each company. We assigned the value ' 0 ' when the measurement method was not adopted by companies and we assigned the value ' 1 ' when the measurement method was adopted by companies.

Data were manually collected from the first annual reports under IFRS, for 2005, available on the companies' websites as well as on the website of Euroland (www.euroland.com). We started by examining the notes containing the statement of accounting policies. In the event that companies fail to indicate any information about financial instruments' measurement requirements in this note, we examined the note on financial instruments and the balance sheet.

On adoption of IFRS, the same accounting policies should also be used at the transition date (end of 2004 financial year) and the adoption date (2005 financial year), except for the exemptions and exceptions to retrospective application of some IFRS, as described in IFRS $1 .^{3}$ The exemptions and exceptions related to financial instruments do not affect our data because all companies that disclosed the information indicated that they used the same policies for financial instruments at transition and adoption dates.

The information on measurement method was collected using a dichotomous classification. We assigned the value 1 for the presence of each item and 0 for the absence of the item. The various options for reporting each item are coded as follows:

- ' 0 ' to 'Not adopted items': this measurement method was not adopted by companies

- ' 1 ' to 'Adopted items': this measurement method was adopted by companies

- 'NP' to 'Not-presented items': companies did not comment on whether they have the transactions or items to which the disclosure item applies

- 'NA' to 'Non-applicable items': companies have no such transactions or items to which disclosure rules apply.

When a company did not disclose a measurement method but was required to do so, the 'not presented' (NP), a ' 0 ', was assigned. We may identify this type of situation, for example, when the company presented held-to-maturity investments in the balance sheet, but the company did not disclose any information about the initial or subsequent measurement of held-to-maturity investments in the notes.

Finally, when a company did not disclose any information about an item, in the balance sheet or in the notes, we considered that the company was not adopting the measurement method because the company was not required to and 'not applicable' (NA) was used. Such cases were excluded from our analyses. Thus possible misclassification can occur if companies do not disclose information, not because they do not have the item, but because they do not comply with IAS 39. In these cases, we should have classified the item as NP instead of NA. The impact of this misclassification is likely to be an overstatement of the JACC index. We are unable to control for this potential measurement error due to lack of company-specific information.

Based on these procedures applied to the range of measurement requirements detailed in Appendix A, and 
following Rahman et al. (2002), we calculated the JACC index for each company and for each country in order to determine the level of compliance with IAS 39 for our sample companies. The calculation was based on the following $2^{*} 2$ table:

\begin{tabular}{|c|c|c|c|c|}
\hline & \multicolumn{2}{|c|}{ Company } & \multirow[b]{2}{*}{ Total } \\
\hline & & 1 & 0 & \\
\hline \multirow{3}{*}{ IAS 39} & 1 & $a$ & $b$ & $a+b$ \\
\hline & 0 & $c$ & $d$ & $c+d$ \\
\hline & Total & $a+c$ & $b+d$ & $a+b+c+d$ \\
\hline
\end{tabular}

Where:

$a=$ The number of matches when the company adopted the specific measurement method required by IAS $39,(1,1)$.

$b=$ The number of mismatches when the company did not adopt the specific measurement method required by IAS $39,(1,0)$.

$c=$ The number of mismatches when company adopted a specific measurement method not permitted by IAS $39(0,1)$.

$d=$ The number of matches when the company did not adopt the measurement method and the measurement method is not required by IAS 39, $(0,0)$.

The JACC index measures the extent of similarity between the practices that were adopted by the company and required by IAS 39. The expression used for the index, for each pair, is translated by the following formula:

$$
J A C C=\frac{a}{a+b+c}
$$

The values of the indexes may vary between 0 and 1 , and the higher the value of the index, the higher the level of compliance of financial instruments reporting practice with IAS 39. After estimating the index by company, we computed the average of the JACC index by country.

The second objective of this paper is to investigate whether the level of compliance with IAS 39 varied because of differences in institutional factors in EU countries. To accomplish this second objective, we applied a linear regression model to relate the dependent variable JACC index to explanatory variables (country, industry, auditor, size, profitability, listing status and year of IFRS adoption). Data for all the independent variables were obtained from the Worldscope Database.

\section{Results}

The JACC index is an index of similarity between the companies' practices and the measurements requirements of IAS 39. The level of compliance of financial instruments reporting practice with IAS 39 was measured with the JACC index, and in Table 3, panel A we present descriptive statistics, by country. We have also computed separately the index with and without financial companies (Table 3, panel B). The mean level of compliance for financial companies was 0.844 and for non-financial companies 0.802 . This indicates that, as predicted, compliance with IAS 39 is higher for financial institutions.

The level of compliance with IAS 39 differs between the countries. From Table 3, panel A it is evident that UK companies present the highest index (0.887), followed by Italian companies (0.871), Portuguese companies (0.856), French companies (0.839) and German companies (0.680). These results suggest that German companies comply less with the measurement practices of IAS 39 than the other European-listed companies. However, the results may reflect lack of disclosure on transition. Some German companies disclosed information about subsequent measurement in the notes, but failed to give information about the initial measurement. In these cases, we considered the items as not presented (NP) and we assigned a ' 0 '. The $\mathrm{NP}$ items have a negative impact on the JACC index, as these cases are observations of mismatches, and the higher the number of NPs, the lower the JACC index.

A comparison test between two means using the Gaussian distribution was conducted to identify if there were any significant differences between the means of JACC indexes by country. The results presented in Table 3 , panel C reveal that the differences between the German mean and the means of all other countries are significant at the $1 \%$ level. In the case of France and the UK the difference between means is significant at the $5 \%$ level.

Untabulated results indicate that in the UK sample there are ten companies (11\%) with a JACC index lower than 0.6. On the other hand, in the other countries there are only one or two companies with an index lower than 0.6. Additionally, for the cases with an index equal to 1 (total compliance) we have eight UK companies (8\%), eight French companies (20\%), six Italian companies $(21 \%)$ and four Portuguese companies (20\%). In the case of Germany, there are no companies with indexes equal to 1 and there are six companies with a JACC index lower than $0.6(15 \%)$. Thus the majority of firms do not comply completely with the requirements of IAS 39. 
Table 3 Jaccard index results by country and by sector

\begin{tabular}{|c|c|c|c|c|c|c|}
\hline \multicolumn{7}{|c|}{ Panel A: Jaccard index: IAS 39 compliance by country } \\
\hline & $\mathrm{N}$ & Minimum & Maximum & Mean & Median & Std dev. \\
\hline France & 40 & 0.571 & 1.000 & 0.839 & 0.846 & 0.123 \\
\hline Germany & 21 & 0.538 & 0.917 & 0.680 & 0.684 & 0.105 \\
\hline Italy & 27 & 0.632 & 1.000 & 0.871 & 0.889 & 0.094 \\
\hline Portugal & 20 & 0.651 & 1.000 & 0.856 & 0.862 & 0.107 \\
\hline United Kingdom & 95 & 0.455 & 1.000 & 0.887 & 0.846 & 0.145 \\
\hline \multicolumn{7}{|c|}{ Panel B: Jaccard index: IAS 39 compliance by sector } \\
\hline & $\mathrm{N}$ & Minimum & Maximum & Mean & Median & Std dev. \\
\hline Financial & 50 & 0.467 & 1.000 & 0.844 & 0.897 & 0.150 \\
\hline Non-financial & 153 & 0.455 & 1.000 & 0.802 & 0.824 & 0.138 \\
\hline
\end{tabular}

Panel C: Differences in means of Jaccard index between countries

\begin{tabular}{lcccc}
\hline & France & Germany & Italy & Portugal \\
\hline Germany & $5.291^{* * *}$ & & & \\
Italy & -1.205 & $-6.543^{* * *}$ & 0.500 & -1.100 \\
Portugal & -0.551 & $-5.313^{* * *}$ & -0.683 & $-7.577^{* * *}$ \\
United Kingdom & $-1.960^{* *}$ & & -100 \\
\hline
\end{tabular}

This table shows significant differences (based on t-test) between the Jaccard indexes for each pair of countries. ${ }^{*},{ }^{* *},{ }^{* * *}$ Significant at the $10 \%, 5 \%$ and $1 \%$ levels of significance, respectively (two-tailed).

A deeper analysis indicates that the diversity between financial instrument accounting practices and IAS 39 is due to the practices adopted on an initial measurement of financial instruments. We found that companies do not adopt the measurement method required by IAS 39 for initial measurement; namely, for the heldto-maturity investments, loans and receivables, and available-for-sale financial assets items, since they did not include transaction costs as required by IAS 39 . In order to evaluate the relevance of this practice, we analysed the audit reports of all the companies included in the sample. We found that none of the companies had qualified reports in relation to accounting for financial instruments. A possible explanation for this is that the non-disclosure of financial information about transaction costs is a minor issue.

In contrast, we observed that, in general, companies comply with the accounting practices required for subsequent measurement of all the categories of financial assets and liabilities. In particular, there is total harmonisation in the case of derivatives as all the companies in the sample adopted the accounting treatment required by IAS 39 .

Since the classification of an item as NA can be problematic, we also decided to analyse whether the number of NAs varies across the countries and across the items. We found that, on average, $22 \%$ of our sample companies had NA items and the number of NA items varies between $17 \%$ in Italy and $27 \%$ in the UK. Indicating some country variations in the NA classifications, the analysis also showed that German and Italian companies had the highest values of NA for the item 'Hedge of a net investment in a foreign operation', with $76 \%$ and $74 \%$, respectively. The UK, French and Portuguese companies had the highest values of NA for the item 'Financial liabilities at fair value through profit and loss', with $62 \%, 78 \%$ and $85 \%$.

Table 4 reports results of a regression model investigating explanatory factors of compliance of the 203 European companies in our sample. The estimated model is statistically significant and the explanatory power evaluated by the adjusted $R^{2}$ is around $11 \%$. With respect to our specific hypotheses, we found that only country and industry are significant explanatory variables. Industry is statistically significant at the $10 \%$ significance level. The results reveal that the estimated coefficient for Germany is negative and statistically significant at the $1 \%$ significance level, suggesting that German companies tend to comply less with IAS 39 than the UK companies. The estimated coefficients of Italy, France and Portugal are positive, but not statistically significant. Except for Germany, we found no evidence that compliance differs across the countries considered in our sample. Additionally, we found no persuasive support for companies' specific factors such as auditor, size, being cross-listed, profitability and number of years of IFRS adoption being related to the level of compliance with IAS $39 .{ }^{4}$

\section{Conclusions}

In this study we provide empirical evidence of the high level of compliance with respect to the measurement requirements in IAS 39 by a sample of Europeanlisted companies, from five different countries, in the 
Table 4 Regression results ${ }^{1}$

\begin{tabular}{|c|c|c|c|}
\hline \multicolumn{4}{|c|}{$\begin{aligned} \operatorname{Ln}(J A C C) & =\alpha_{0}+\alpha_{1} \text { FRANCE }_{i}+\alpha_{2} \text { ITALY }_{i}+\alpha_{3} \text { PORTUGAL }_{i}+ \\
& +\alpha_{4} \text { GERMANY }_{i}+\alpha_{5} \text { INDUSTRY }_{i}+\alpha_{6} \text { AUDITOR }_{i}+ \\
& +\alpha_{7} \text { Ln }(\text { MVE })_{i}+\alpha_{8} \text { INT }_{i}+\alpha_{9} \text { TDTA }_{i}+\alpha_{10} \text { NITA }_{i}+ \\
& +\alpha_{11} \text { PASTADOPT }_{i}+\varepsilon_{i}\end{aligned}$} \\
\hline & Estimated sign & Coefficient & $t$-statistic \\
\hline C & & -0.301 & $-1.663^{*}$ \\
\hline FRANCE & - & 0.030 & 0.800 \\
\hline ITALY & - & 0.069 & 1.617 \\
\hline PORTUGAL & - & 0.067 & 1.275 \\
\hline GERMANY & - & -0.147 & $-2.526^{* * *}$ \\
\hline INDUSTRY & + & 0.066 & $1.915^{*}$ \\
\hline AUDITOR & + & -0.050 & -0.935 \\
\hline Ln(MVE) & + & 0.005 & 0.476 \\
\hline INT & + & 0.003 & 0.115 \\
\hline TDTA & $?$ & 0.001 & 0.808 \\
\hline NITA & $?$ & 0.086 & 0.427 \\
\hline PASTADOPT & + & -0.008 & -0.148 \\
\hline N & & 203 & \\
\hline Adjusted $R^{2}$ & & 0.106 & \\
\hline F statistic & & $3.125^{\text {*** }}$ & \\
\hline
\end{tabular}

$*, * *, * * *$ Significant at the $10 \%, 5 \%$ and $1 \%$ levels of significance, respectively.

This table presents the results of regression models that examine the relationship between the logarithm of JACC index and independent variables for the full sample of 203 European companies listed in CAC40, DAX30, MIB30, PSI20 and FTSE100. FRANCE assumes the value 1 if the company $i$ is from France and 0 otherwise; ITALY assumes the value 1 if the company $i$ is from Italy and 0 otherwise; PORTUGAL assumes the value 1 if the company $i$ is from Portugal and 0 otherwise; GERMANY assumes the value 1 if the company $i$ is from Germany and 0 otherwise; INDUSTRY assumes the value 1 if company $i$ is a financial institution and 0 otherwise; AUDITOR assumes the value 1 if company $i$ is audited by one of the BIG 4 and 0 otherwise; In(MVE) is the logarithm of market value of equity of company $i$; INT assumes the value 1 if the company $i$ is listed in more than one market and 0 otherwise; TDTA is the ratio total debt/total assets for company $i$; NITA is the ratio net income/total assets for company $i$; and PASTADOPT assumes the value 1 if the company adopted IASB standards before 2005 and 0 otherwise.

${ }^{1}$ We also estimated the same linear regression model without logging the Jaccard index and we found similar results (results not tabulated).

first year of mandatory adoption. Despite the fact that we studied the first year of mandatory adoption of a complex standard, IAS 39, the results of the JACC index showed a high level of compliance with financial instrument measurement requirements. We observed almost full compliance with IAS 39 in all five countries for subsequent measurement practices. There was less compliance in relation to disclosure of initial measurement policies in Germany. However, no company had a qualified audit report, suggesting the non-disclosure was not a material issue.

Multivariate analysis showed that level of compliance was not affected by institutional factors or company factors as predicted. Aside from the difference noted above in relation to Germany, we did not observe country differences as explanatory factors for compliance. This suggests that institutional factors had less influence, at least in relation to IAS 39 in the first year, than was expected. Financial sector companies demonstrated greater compliance than other companies. Other company variables (auditor, size, being cross-listed, profitability and number of years of IFRS adoption) were not significant explanatory factors.

Although previous studies have found that formal harmonisation does not necessarily lead to a complete material harmonisation (Cairns 2000; Street et al. 1999; Street and Bryant 2000; Bradshaw and Miller 2008; Rahman et al. 2002; Ball et al. 2003), our findings show a high level of compliance of financial instrument measurement practices with IAS 39, for the first year of mandatory adoption. The result is a positive signal for the harmonisation of financial reporting of EU companies.

Ana Isabel Morais is at the ISCTE Business School. Ana Fialho is at the Universidade de Evora.

\section{Notes}

1 Since 1998, German companies that are both the parent company of a group and listed on a stock exchange have been able to opt for producing their group accounts according to IFRS or US GAAP. After IASB standards became mandatory in 2005, Germany made the provision that the requirement to adopt IASB standards should only apply to the financial year starting on or after January 2007, in relation to companies that had been using US GAAP.

2 The modified version of IAS 39 contains carve-outs that affect two parts of IAS 39: the fair value option and the hedge accounting requirements. IAS 39, issued by IASB, provided an option to fair value all financial assets and liabilities without any restrictions by designating them as financial assets or liabilities at fair value through profit or loss. However, the standard adopted by the EU did not include this option. In terms of hedge accounting, IAS 39 adopted by the $\mathrm{EU}$ was less restrictive because the Commission deleted some conditions. These two differences do not affect our checklist.

3 IFRS 1 allows limited exemptions from retrospective application of some IFRS in specified areas where the cost of applying IFRS retrospectively may exceed the benefits to users of financial statements. IFRS 1 also prohibits retrospective application of IFRS in some areas where retrospective application may require judgments by management about past conditions after the outcome of a particular transaction. If companies elect to use an exemption or are required to apply an exception, then the accounting policies adopted in the opening IFRS balance sheet will be different from the accounting policies adopted in the comparative period and in the reporting period.

4 We also included leverage as a possible explanatory factor with no significant result.

\section{References}

Al-Shammari, P. Brown and A. Tarca 2008, 'An investigation of compliance with international accounting standards by listed 
companies in the Gulf Co-Operation Council Member States', forthcoming, The International Journal of Accounting.

Ball, R. 2006, 'International Financial Reporting Standards (IFRS): Pros and cons for investors', Accounting \& Business Research, 36, Special Issue: 5-27.

Ball, R., A. Robin and J.S. Wu 2003, 'Incentives versus standards: Properties of accounting income in four East Asian countries', Journal of Accounting and Economics, 36, 1-3: 23570 .

Barth, M.E., W.R. Landsman and M. Lang 2008, 'International accounting standards and accounting quality', forthcoming, Journal of Accounting Research.

Bradshaw, M.T. and G.S. Miller 2008, 'Will harmonizing accounting standards really harmonize accounting? Evidence from non-US firms adopting U.S. GAAP', forthcoming, Journal of Accounting, Auditing and Finance.

Cairns, D. 2000, International Accounting Standards Survey 2000, David Cairns.

Chalmers, K. and J.M. Godfrey 2004, 'Reputation costs: The impetus for voluntary derivative financial instrument reporting', Accounting, Organizations and Society, 29, 2: 95125.

Committee of European Securities Regulators (CESR) 2003, Standards No. 1 on Financial Information: Enforcement of Standards on Financial Information In Europe, CESR/03-073, March.

Cooke, T.E. 1989, 'Disclosure in the corporate annual reports of Swedish companies', Accounting and Business Research, 19, 74: 113-24.

Cooke, T.E. 1992, 'The impact of size, stock market listing and industry type on disclosure in the annual reports of Japaneselisted corporations', Accounting and Business Review, 22, 87: 229-37.

Demirgüç-Kunt, A. and R. Levine 1999, 'Bank-based and market-based financial systems: Cross-country comparisons', Policy Research Working Paper 2143, World Bank, Development Research Group, Finance, Washington, July.

Dunne, T.M, C.V. Helliar, C.A. Mallin, L. Moir, K.H. Ow-Yong and D.M. Power 2003, 'The financial reporting of derivatives and other financial instruments: A study of the implementation and disclosures of FRS 13', ICAEW, London.

European Central Bank 2004, 'Fair value accounting and financial stability', Occasional Paper Series 13, April.

Faccio, M. and L.H. Lang 2002, 'The ultimate ownership of Western European corporations', Journal of Financial Economics, 65: 365-95.

Firth, M. 1979, 'The impact of size, stock market listing and auditors on voluntary disclosure in corporate annual reports', Accounting Business Research, Autumn: 272-80.

Francis, J. and D. Wang 2008, 'The joint effect of investor protection and Big 4 audits on earnings quality around the world', Contemporary Accounting Research, 25, 1: 91-157.
Glaum, M. and D. L. Street 2003, 'Compliance with the disclosure requirements of Germay's new market: IAS versus US GAAP', Journal of International Financial Management and Accounting, 14, 1: 64-100.

Holthausen, R.W. and R. Leftwich 1983, 'The economic consequences of accounting choice: Implication of costly contracting and monitoring, Journal of Accounting and Economics, 5: 77-117.

International Accounting Standards Board (IASB) 2004, IFRS 1 First-Time Adoption of International Financial Reporting Standards.

International Accounting Standards Board 2005, IAS 39 Financial Instruments: Recognition and Measurement.

Krishnan, G. 2003, 'Audit quality and the pricing of discretionary accruals', Auditing: A Journal of Practice and Theory, 22: 109-126.

La Porta, R., F. López-de-Silanes A. Shleifer and R.W. Vishny 1998, 'Law and finance', Journal of Political Economy, 106: 111350.

La Porta, R.F. López-de-Silanes and A. Shleifer 2006, 'What works in securities laws?', Journal of Finance, 61: 132.

Leuz, C. and R.E. Verrechia 2000, 'The economic consequences of increased disclosure', Journal of Accounting Research, 38: 91124.

McLeay, S.J. and A. Jaafar 2007, 'Country effects and sector effects on the harmonization of accounting policy choice', Abacus, 43, 2: 156-89.

Meek, G.K., C.B. Roberts and S.J. Gray 1995, 'Factors influencing voluntary annual report disclosures by US, UK and continental European multinational corporations', Journal of International Business Studies, 26, 3: 555-72.

Raffournier, B. 1995, 'The determinants of voluntary financial disclosure by Swiss-listed companies', European Accounting Review, 4, 2: 261-80.

Rahman, A.R., M.H. Perera and S. Ganesh 2002, 'Measurement practice harmony, accounting regulation and firm characteristics', Abacus, 38, 1: 46-77.

Singhvi, S.S. and H.B. Desai 1971, 'An empirical analysis of the quality of corporate financial disclosures', The Accounting Review, 46, 1: 129-38.

Soewarso, E.N., G.D. Tower, P. Hancock and R.H. Taplin 2003, 'A comparative study of de jure and de facto disclosures between Australia and Singapore', Asian Review of Accounting, 11, 1: 18-47.

Street, D.L. and S.M. Bryant 2000, 'Disclosure level and compliance with IASs: A comparison of compliance with and without US listings and filings', The International Journal of Accounting, 35, 3: 305-29.

Street, D.L. and S.J. Gray 2001, 'Observance of international accounting standards: Factors explaining non-compliance by 
companies referring to the use of IAS', ACCA Research Monograph, 74, London.

Street, D.L., S.J. Gray and S.M. Bryant 1999, 'Acceptance and observance of international accounting standards: An empirical study of companies claiming to comply with IASs', The International Journal of Accounting, 34, 1: 1148.

Taplin, R.H., G.D. Tower and P. Hancock 2002, 'Disclosure (discernibility) and compliance of accounting policies: Asia-Pacific evidence', Accounting Forum, 26, 2: 172190.

Teoh, S.H. and T.J. Wong 1993, 'Perceived auditor quality and the earnings response coefficient', The Accounting Review, 68: 346-66.

Tower, G.D., P. Hancock and R.H. Taplin 1999, 'A regional study of listed companies' compliance with international accounting standards', Accounting Forum, 23, 3: 293305.
Van der Tas, L.G. 1988, 'Measuring harmonization of financial reporting practice', Accounting and Business Research, 18, 70: 157-69.

Wallace, R.S.O. and K. Nasser 1995, 'Firm-specific determinants of the comprehensiveness of mandatory disclosure in the corporate annual reports of firms listed on the stock exchange of Hong Kong', Journal of Accounting and Public Policy, 14, 2 : 311-68.

Wallace, R.S., K. Nasser and A. Mora 1994, 'The relationship between the comprehensiveness of corporate annual reports and firm characteristics in Spain', Accounting and Business Research, 25, 97: 41-53.

Watts, R.L. and J.L. Zimmerman 1978, 'Towards a positive theory of the determination of accounting standards', The Accounting Review, 53, 1: 112-34.

Woods, M. and D.E. Marginson 2004, 'Accounting for derivatives: An evaluation of reporting practice by UK banks', European Accounting Review, 13, 2: 373-90. 


\section{Appendix A Compliance Checklist}

\begin{tabular}{|c|c|c|c|}
\hline & Items & IAS 39 & Companies \\
\hline 1 & Financial assets at fair value through profit or loss & & \\
\hline \multirow[t]{3}{*}{1.1} & Initial measurement & & \\
\hline & 1.1.1 Fair value plus transaction costs & 0 & $(1$ or 0$)$ \\
\hline & 1.1.2 Fair value & 1 & $(1$ or 0$)$ \\
\hline \multirow[t]{6}{*}{1.2} & Subsequent measurement & & \\
\hline & 1.2.1 Cost & 0 & $(1$ or 0$)$ \\
\hline & 1.2.2 Amortised cost & 0 & $(1$ or 0$)$ \\
\hline & 1.2.3 Fair value in profit or loss & 1 & $(1$ or 0$)$ \\
\hline & 1.2.4 Fair value in equity & 0 & $(1$ or 0$)$ \\
\hline & 1.2.5 Impairment & 0 & $(1$ or 0$)$ \\
\hline 2 & Held to maturity investments & & \\
\hline \multirow[t]{3}{*}{2.1} & Initial measurement & & \\
\hline & 2.1.1 Fair value plus transaction costs & 1 & $(1$ or 0$)$ \\
\hline & 2.1.2 Fair value & 0 & $(1$ or 0$)$ \\
\hline \multirow[t]{6}{*}{2.2} & Subsequent measurement & & \\
\hline & 2.2.1 Cost & 0 & $(1$ or 0$)$ \\
\hline & 2.2.2 Amortised cost & 1 & $(1$ or 0$)$ \\
\hline & 2.2.3 Fair value in profit and loss & 0 & $(1$ or 0$)$ \\
\hline & 2.2.4 Fair value in equity & 0 & $(1$ or 0$)$ \\
\hline & 2.2.5 Impairment & 1 & $(1$ or 0$)$ \\
\hline 3 & Loans and receivables & & \\
\hline \multirow[t]{3}{*}{3.1} & Initial measurement & & \\
\hline & 3.1.1 Fair value plus transaction costs & 1 & $(1$ or 0$)$ \\
\hline & 3.1.2 Fair value & 0 & $(1$ or 0$)$ \\
\hline \multirow[t]{6}{*}{3.2} & Subsequent measurement & & \\
\hline & 3.2.1 Cost & 0 & $(1$ or 0$)$ \\
\hline & 3.2.2 Amortised cost & 1 & $(1$ or 0$)$ \\
\hline & 3.2.3 Fair value in profit and loss & 0 & $(1$ or 0$)$ \\
\hline & 3.2.4 Fair value in equity & 0 & $(1$ or 0$)$ \\
\hline & 3.2.5 Impairment & 1 & $(1$ or 0$)$ \\
\hline 4 & Available-for-sale financial assets & & \\
\hline \multirow[t]{3}{*}{4.1} & Initial measurement & & \\
\hline & 4.1.1 Fair value plus transaction costs & 1 & $(1$ or 0$)$ \\
\hline & 4.1.2 Fair value & 0 & $(1$ or 0$)$ \\
\hline \multirow[t]{6}{*}{4.2} & Subsequent measurement & & \\
\hline & 4.2.1 Cost & 1 & $(1$ or 0$)$ \\
\hline & 4.2.2 Amortised cost & 0 & $(1$ or 0$)$ \\
\hline & 4.2.3 Fair value in profit and loss & 0 & $(1$ or 0$)$ \\
\hline & 4.2.4 Fair value in equity & 1 & $(1$ or 0$)$ \\
\hline & 4.2.5 Impairment & 1 & $(1$ or 0$)$ \\
\hline 5 & Financial liabilities at fair value through profit and loss & & \\
\hline \multirow[t]{3}{*}{5.1} & Initial measurement & & \\
\hline & 5.1.1 Fair value plus transaction costs & 0 & $(1$ or 0$)$ \\
\hline & 5.1.2 Fair value & 1 & $(1$ or 0$)$ \\
\hline \multirow[t]{6}{*}{5.2} & Subsequent measurement & & \\
\hline & 5.2.1 Cost & 0 & $(1$ or 0$)$ \\
\hline & 5.2.2 Amortised cost & 0 & $(1$ or 0$)$ \\
\hline & 5.2.3 Fair value in profit and loss & 1 & $(1$ or 0$)$ \\
\hline & 5.2.4 Fair value in equity & 0 & $(1$ or 0$)$ \\
\hline & 5.2.5 Impairment & 0 & $(1$ or 0$)$ \\
\hline 6 & Other financial liabilities & & \\
\hline \multirow[t]{3}{*}{6.1} & Initial measurement & & \\
\hline & 6.1.1 Fair value plus transaction costs & 1 & $(1$ or 0$)$ \\
\hline & 6.1.2 Fair value & 0 & $(1$ or 0$)$ \\
\hline \multirow[t]{6}{*}{6.2} & Subsequent measurement & & \\
\hline & 6.2.1 Cost & 0 & $(1$ or 0$)$ \\
\hline & 6.2.2 Amortised cost & 1 & $(1$ or 0$)$ \\
\hline & 6.2.3 Fair value in profit and loss & 0 & $(1$ or 0$)$ \\
\hline & 6.2.4 Fair value in equity & 0 & $(1$ or 0$)$ \\
\hline & 6.2 .5 Impairment & 0 & $(1$ or 0$)$ \\
\hline
\end{tabular}




\section{Items}

$7 \quad$ Derivatives

7.1

7.2

7.3

7.4
Fair value hedge

7.1.1 Profit and loss

7.1.2 Equity

7.1.3 Deferral

Cash flow hedge

7.2.1 Profit and loss

7.2.2 Equity

7.2.3 Deferral

Hedge of a net investment in a foreign operation

7.3.1 Profit and loss

7.3.2 Equity

7.3.3 Deferral

Financial assets or liabilities at fair value through profit and loss

7.4.1 Profit and loss

7.4.2 Equity

7.4.3 Deferral
IAS 39

Companies

\section{1}

0

0

1 or 0$)$

(1 or 0 )

(1 or 0 )

0

1

0

(1 or 0$)$

(1 or 0$)$

(1 or 0 )

(1 or 0$)$

(1 or 0$)$

(1 or 0 )

(1 or 0)

(1 or 0 )

(1 or 0 ) 